\title{
Glutathione S-Transferase M1 Genetic Polymorphism Is Associated With Salivary 17- Bestradiol Levels: A Study Based On Hormonal Profiles From Entire Menstrual Cycles
}

\section{Citation}

Furberg, Anne-Sofie, Anne McTiernan, Peter T. Ellison, Karen W. Makar, Amy Iversen, Aina Emaus, Inger Thune. 2008. Glutathione S-transferase M1 genetic polymorphism is associated with salivary 17-Bestradiol levels: A study based on hormonal profiles from entire menstrual cycles. 20th Meeting of the European Association for Cancer Research. European Journal of Cancer Supplement 6(9): 207.

\section{Published Version}

http://dx.doi.org/10.1016/S1359-6349(08)71910-4

\section{Permanent link}

http://nrs.harvard.edu/urn-3:HUL.InstRepos:3008264

\section{Terms of Use}

This article was downloaded from Harvard University's DASH repository, and is made available under the terms and conditions applicable to Open Access Policy Articles, as set forth at http:// nrs.harvard.edu/urn-3:HUL.InstRepos:dash.current.terms-of-use\#OAP

\section{Share Your Story}

The Harvard community has made this article openly available.

Please share how this access benefits you. Submit a story.

\section{Accessibility}


Glutathione S-transferase M1 genetic polymorphism is associated with salivary 17ßestradiol levels. A study based on hormonal profiles from entire menstrual cycles Anne-Sofie Furberg, Anne McTiernan, Peter T. Ellison, Karen W. Makar, Amy Iversen, Aina Emaus, Inger Thune
Abstract:
Introduction: Studies suggest that enzymes involved in the estrogen metabolic pathway are susceptibility factors for breast cancer; however, there is limited direct evidence in relation to estradiol levels. The glutathione-S-transferase M1 enzyme (GSTM1) enzyme is involved in estrogen peroxidation, and a shortage seems to enhance estrogen exposure. A homozygous deletion of the GSTM1 gene leads to total absence of enzyme activity, and studies indicate that an association with breast cancer risk may be modified by body mass. So far, parallel studies on intermediate biomarkers (i.e. estradiol) are largely missing. Thus, in the present study, we assessed the association between a GSTM1 genetic polymorphism (null/rs1065411) and daily salivary levels of 17-ßestradiol throughout one entire menstrual cycle and evaluated modification of genotype effects according to metabolic profile in 190 premenopausal women aged 25-35 years. Methods: The women participated in the Energy Balance and Breast Cancer Aspects study (EBBA-I, 2000-2002) in Tromsø, North Norway (inclusion criteria: healthy, non- pregnant, non-lactating, no current use of exogenous hormones). Salivary levels of 17- ßestradiol were assessed by radioimmunoassay (The Reproductive Ecology Laboratory, Harvard University). Height and weight were measured. Genomic DNA was extracted from EDTAwhole blood. GSTM1 genotyping was done on the ABI PRISM ${ }^{\circledR} 3100$ Genetic Analyzer (Fred Hutchinson Cancer Research Center). The GSTM1 assay distinguishes between the GSTM1*Aallele (G nucleotide, Lys at aminoacid 173), the GSTM1*B allele (C nucleotide, Asn at aminoacid 173), and the homozygous gene deletion. Regression models were used to study the relation between genetic (null genotype versus all other alleles combined) and metabolic susceptibility factors, and

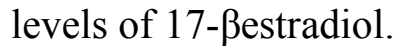
Results: Mean body mass index (BMI) was $24.4 \mathrm{~kg} / \mathrm{m} 2$. The homozygous gene deletion of GSTM1 had a prevalence of $52 \%$, and the frequency of the null genotype was similar in heavy women (BMI $\geq 26.3 \mathrm{~kg} / \mathrm{m} 2$, upper quartile) as compared to other women ( $\mathrm{p}=$ .18). The null genotype was associated with lower levels of 17- $\beta$ estradiol by cycle day compared to other alleles $(\mathrm{p}=.04)$. However, the association was confined to women that were normal weight to slightly overweight ( $\mathrm{p}$ for interaction $=.01)$. In women with BMI $<26.3 \mathrm{~kg} / \mathrm{m} 2$, the null genotype was associated with significantly lower levels of 17 - $\beta$ estradiol by cycle day compared to other alleles $(\mathrm{p}=.02)$ and an $18 \%$ reduction in overall average level of $17-\beta$ estradiol throughout the cycle $(p=.02)$, while in heavy women no association with estradiol levels was observed.
Conclusion: In our study, GSTM1 genotype was a significant determinant of circulating estradiol levels in premenopausal women without marked adiposity. Thus, interestingly our results strongly support that the effect of body mass on estradiol levels and subsequent breast cancer development may be modified by GSTM1 genotype. 